\title{
On the Construction of College English Listening and Speaking Ecological Classroom From the Perspective of Eco-Linguistics
}

\author{
Xiaojing Chen \\ School of Foreign Language, Huaiyin Institute of Technology, Jiangsu, China
}

\begin{abstract}
Ecological approaches to language learning and teaching have captured the interest of language educators as both native and non-native speakers find themselves operating in increasingly multilingual and multicultural environments. Based on ecolinguistics, this paper describes what an ecological perspective on college English listening and speaking class would look like. It first explains some major concepts related to ecolingustics, and analyses problems on current ecological imbalances in college English and speaking classrooms and proposes strategies for building a harmonious ecological classroom through language education in institutional contexts.
\end{abstract}

Index Terms — ecolinguistics, ecosystem, teachers' niche, students' niche

\section{INTRODUCTION}

Ecolinguistics, also known as ecology of language, is an emerging discipline that combines ecology and linguistics. Its ideas provide a new research paradigm for foreign language teaching. The concept of "language ecology" (Haugen Einar, 1972), first proposed by Einar Huagen, a scholar at Stanford University in the United States, derived from natural ecological system, holds that language, like biology, also has its own ecological environment and emphasizes the interaction between language and social ecological environment. Since1980s, linguists began to pay attention to the development of ecolinguistics and apply it to language teaching which gradually lead to the combination of ecolinguistics and language teaching. According to those linguistics, educational ecology refers to the research methods of ecology and pedagogy to study the ecological problems in education. In educational ecology, classroom is regarded as a system with ecological attributes and characteristics, all elements within it are interrelated. Teachers, students and teaching environment are the three most important ecological elements in classroom ecosystem. The relationship between them is interdependent and interactive, forming a diversified interaction. The ill development of any ecological element may cause a chain reaction and lead to the imbalance of classroom ecology, which inevitably affect the efficiency of language teaching.

Based on ecolinguistics, English classroom is a complete ecosystem with various ecological elements affecting and restricting one another. The main ecological elements include teachers, students, classroom environment etc. In which, classroom environment includes micro and macro environment. Macro environment involves social environment, campus environment and curriculum setting. Micro classroom environment includes classroom equipment, teaching concept, teacher-student relationship and classroom discipline. Successful integration of these elements and information technology is the key to a healthy and sustainable teaching ecology. Only when the ecological elements develop harmoniously in college English listening and speaking teaching ecosystem, and have a relatively stable, balanced and virtuous cycle of English listening and speaking teaching ecological environment, a dynamic and balanced ecosystem with interaction, symbiosis, competition and bionics can be built in class. Current college English listening and speaking teaching, however, is witnessing many challenges caused by imbalances in the class ecosystem.

\section{ECOlogical Imbalance in ColLege English Listening AND Speaking Class}

\section{A. Over Developed Teachers' Ecological Niche}

The essence of classroom teaching is to promote a process of sustainable development in which teachers and students cooperate and explore knowledge together. In current English listening and speaking classroom, the development of the niche of both teachers and students, two important elements in college English listening and speaking class, is out of balance.

Teachers' niche generally refers to their role in class in the process of knowledge transfer, exchange and transformation with students. At present, teachers have too much power in classroom: teachers dominate almost all the activities in class, and are almost the only "producer" of English knowledge and information. The classroom teaching mode still presents the characteristics of "one speech", and teachers are still the authority of the classroom and knowledge due to their excessive control of the classroom. The modern teaching concept of "student-centered" has not been well practiced. Meanwhile, students are not well acknowledged their ecological roles in classroom, they are still 
passive knowledge receivers and "consumers". And in listening and speaking class, teachers' teaching method is still like this: play listening materials -- ask students questions -- answer the materials -- proofread listening materials, in which, teachers are the publishers of knowledge, while students are passive receivers of knowledge. There is no process of knowledge transforming and absorbing, and there is a lack of positive interaction between teachers and students. Cheng Xiaotang (2016) believes that teachers and students are the main sources of knowledge, Teachers should deeply understand the significance of classroom interaction and cultivate the awareness of classroom interaction; they should design some activities that teachers and students could interact with each other on the combination of teaching purpose and content. At present, due to the lack of awareness of interaction and the lack of well designed curriculum, English teachers in high schools often fail to achieve a satisfactory effect in developing students' listening and speaking competence though they spend a lot of time and efforts. And actions should be taken to improve current situation.

As an ecological element in the system, English teachers fail to cooperate with other elements to build a perfect ecosystem. Because their self-development lags behind, their information literacy couldn't cope with the need of high-tech based teaching method, they fail to bring effective application of computer and internet to English listening and speaking classroom. Some English teachers are still used to the traditional teaching mode. More efforts should be made to the complementary advantages of the new teaching mode highly integrated with modern information technology. Rich teaching resources, such as all kinds of learning and teaching apps and online resources can not be integrated into the classroom, which will virtually affect teachers' arrangement of classroom content and design of class organization. These problems directly lead to teachers' excessive participation in the classroom, and the imbalance of teacher-student ecological niche directly affects the function of teacher-student ecological elements and the harmonious development of English classroom ecosystem.

\section{B. Lack of Students' Ecological Niche}

Classroom is a natural and open ecological system composed of various elements and environment in a certain space. In this system, all elements depend on and interact with each other in the survival process, forming a healthy and orderly state (Chen Jianlin, 2010). Therefore, the role and function of any ecological element in the classroom will inevitably affect others. As the most important ecological elements in the construction of ecological classroom of College English listening and speaking, students' ecological niche face some problems in forming a well developed ecosystem.

As the core of classroom ecosystem, most students haven't yet realized they are the main body of classroom activities, they just act as passive participants, they don't have sustainable learning concept. Many students lack intrinsic learning motivation, such as weak desire for knowledge, lack of interest in understanding the world and curiosity to explore the mysteries of the world, lack of learning initiative and creativity. Under such circumstance, sustainable individual development will not appear, autonomous learning will not happen.

Influenced by traditional "Teacher centered" teaching mode, most students see themselves as subordinates in the process of language learning. The hegemonic position of teachers in the classroom makes it difficult for students to reflect their status as the main body of language learning. Students, as major element of classroom ecology, are not effectively integrated into classroom activities. As a result, there are many cases of students with high academic scores and low language ability or low efficiency of language learning, and students' language ability is not well developed.

The lack of "group effect" among students is another problem. One of the most important factors in College English listening and speaking class is the atmosphere of group learning. The interaction and communication mode of students within and among groups will cause a series of reactions in language learning, which of course are beneficial to their language development. In College English listening and speaking class, with continuous language learning, the differences of students' listening and speaking ability between individuals and groups are becoming more and more obvious, showing obvious polarization phenomenon, which causes great physiological and psychological pressure on students who are in the "slow", "middle and low" or even "low" level in learning. These students are easy to self denial and burnout, or even give up language learning completely. In the long run, if teachers just neglect the problem, it is not conducive to the development of students' individual niche, nor as to the healthy and harmonious development of classroom ecological environment.

In addition, most students don't know how to use metacognitive strategies to guide their language learning. Metacognitive strategies can be adopted to monitor learners' cognitive activities. They are closely in connection with contemplating the learning process, designing learning plans, supervising learning tasks, and commenting one's performance in the learning process (O'Malley and Chamot, 1990). It's a shame that so many of the students have little knowledge about it. Without the knowledge, they couldn't realize autonomy and independence of learning, self-management and self-supervision can not be well achieved, and tasks assigned by teachers before and after class can not be successfully completed, which has a certain impact on the effect of language teaching and learning. Meanwhile, a considerable proportion of teachers and students' perception of the two factors of "student participation" and "classroom co construction" is generally not high, which means that students' participation in the classroom is not enough, and they lack the consciousness of "classroom subjectivity". In short, the poor cooperation with each other is another factor leading to the deviation of teachers' and students' niche.

C. The Imbalance of Ecological Environment in College English Listening and Speaking Classroom 
Ecological overload is a common phenomenon in College English classroom, and it is also an important reason for the time-consuming and inefficient College English teaching. If the ecological classroom is compared to a pond, students are like fish growing up in it. The number of fish that a pond can hold is limited. If there are too many fish, they will not be able to get enough resources. At present, most colleges and universities expand enrollment scale every year, resulting in a sharp increase in the number of students. The class population density basically exceeds the endurance and tolerance of system resources, which violates the principle of moderation. Great individual differences exist among students and their English abilities are uneven in such big classes, meanwhile foreign language teachers are relatively insufficient. In such overload class, it is difficult for teachers to take into account the individual needs of each student. The process of large class teaching will lead to certain obstacles in the development of teaching activities, and the reduction of students' enthusiasm to participate in classroom activities, which will inevitably affect teaching effect and students' learning effect. English is a language, in the learning process, we need to provide students with proper language environment, so that students' English learning ability can be improved in all aspects. But in such big class, it is difficult to provide students a good language learning environment.

With the rapid development of educational network technology, the combination of traditional teaching mode with online learning and mobile learning is a new trend in the development of College English teaching, which makes great changes in the ecological environment of English listening and speaking class, such as, the increase of ecological factors, and the multi-dimensional adjustment of ecological subjects. Nowadays, in the process of teaching, teachers are required to use not only blackboard and multimedia equipment, but also network technology to carry out teaching activities, including network audio and video, network teaching clips, MOOCS or teaching apps. However, students often lose their concentration and attention in the teaching activities due to their lack of self-control in such high-tech class. In classroom online learning, they will be involuntarily attracted to other interfaces of mobile devices such as computers or mobile phones. Especially in teaching task links based on mobile app, it is difficult for teachers to control what students do with their high-tech learning equipment and students are easily distracted from what they are required to do. Effective strategy should be adopted to avoid such things happen.

\section{Classroom Ecological Optimization Strategy}

\section{A. The Upgrading of Teachers' Niche}

In nature, only when a pond is injected with living water and exchanged with the outside world, can all factors in the pond maintain vigorous vitality. It's the same when it comes to language teaching. The closed or semi closed teaching ecological environment will lead to the decline of individual ecological threshold, narrow ecological range and decrease of ecological value. In College English classroom ecosystem, the role of teachers determines whether the ecosystem can operate well or not. As the main element of classroom ecology, English teachers act as knowledge transfers and producers in the ecosystem, and also the output of information. To optimize teachers' ecological niche, College English teachers should begin with advanced beliefs. Chen Jianlin ( 2006) pointed out that foreign language teachers should first keep pace with the times and build correct teaching beliefs with the development of information technology. In addition to knowledge structure and professional ethnics, teachers should possess reflective and critical teaching attitudes. They should know they are the assistant and helper instead of dominant in students' process of language learning. Therefore, teacher's role can be redefined as pre-class curriculum planner, the leader and evaluator of class as well as after-class collaborator. In a word, English teachers should do a good job in changing their roles, from the master of the classroom to the constructors, guides, coordinators and supervisors of ecological classroom.

Professional knowledge is the basic guarantee for teachers to perform the functions of production and transformation of knowledge; Modern educational technology can help teachers achieve higher efficiency and better effect when they export knowledge. Thus, teachers' information literacy is also required in an all round ecological classroom. With the knowledge they can know how to use "living books" and possess the ability of creating a virtual environment. Virtue environment is a good way to connect and monitor students' inside and outside classroom activities. They can train students' autonomous learning, and become provider, and leader of self-learning resources. And, they should also participate in students' self-learning as an equal.

Besides self-learning and training, a training system should also be a support for English teachers' development. Under a systematic training, teachers can accept a continuous educational training, and upgrade their teaching concept, promote teaching methods diversification and improve the interaction ability of information techniques and courses. In a word, a teacher who keeps a clear view of the basic ecological principles can ignite students' sparks of interest that in turn can set in motion perceptual, social and cognitive processes that instigate learning

\section{B. Optimization of Students' Niche}

An ecological approach sees the learner as a whole person, not a grammar production unit. This involves having meaningful things to do and say, being taken seriously, being given responsibility, and being encouraged to tackle challenging projects, to think critically, and to take control of one's own learning. The teacher provides assistance, but only just enough and just in time, taking the learner's developing skills and interests as the true driving force of the curriculum (van Lier, L 2004).

To optimize students' ecological niche, teachers first should enhance students' subject consciousness as ecological 
population, strengthen students' subject status in learning, and pay attention to students' ecological subject from the perspective of development. A completely passive learner will not learn. Students should know they are the center of College English listening and speaking class, not passive knowledge receivers, they should turn themselves from passive into active participants, make active use of good personalized and autonomous learning environment, actively explore and enjoy the learning process. Students must really become the masters of their own learning. Only with teachers as the guide and students as the main body or center can students' niche be correctly positioned. In a word, it is an essential step to establish the dominant status of students and make them form a strong self-awareness and desire to optimize the individual niche in College English listening and speaking class.

Change "isolated passive learning" to "cooperative active learning" is another way to optimize students' niche. It is easy for students to believe that language learning must be accompanied by teachers in traditional college English classroom. Traditional teaching mode makes students be in the subordinate niche of "being instilled" in the classroom ecology, and lack of the motivation and ability of independent learning. The cooperative interaction between students can inject new vitality into the classroom ecosystem, which can promote students to learn from each other, reflect on their learning process、strategies and achievements, and then carry out higher quality autonomous learning. Cooperative learning is the promotion and sublimation of students' individual independent learning.

It is important to note that online interaction of college students will be affected by many factors, such as learning attitude, learning strategy, time management ability, communication ability, network environment, etc., so it is necessary for teachers to organize and intervene students' online interactive learning properly. Because the number of students in College English classroom is relatively large, it is difficult to give every student sufficient language training opportunities in a limited period of time. English teachers should properly deal with the relationship between cooperation and competition between students, form an incentive effect of benign competition, help students increase their confidence and enthusiasm for language learning, improve the methods and strategies of language learning, cultivate critical thinking and communication skills, and finally realize the improvement of English ability and the overall development of individuals.

\section{Co-Development between Teachers and Students}

The coordination between teachers and students is vital for classroom ecology. First of all, the niche of teachers and students complement each other. English teachers' role is to help students acquire knowledge and develop language ability, while students' main task is to improve their language ability with the help of teachers. In traditional teaching mode, teachers and students exchange information and emotions through face-to-face interaction. Teachers guide students and students give teachers feedback on teaching and learning. In ecological teaching mode, teachers first carefully study the teaching materials, and then rely on their teaching knowledge, integrated with their information literacy, to design learning activities in class and online for students. Students complete the task through communication, brainstorming and cooperation in and after class. In the process, teachers give appropriate guidance, and teachers and students evaluate and summarize together after completing the task. In the whole process of language teaching, teachers are not act only as teachers, but also as guides and cooperators of the students. This kind of teaching mode is helpful to the mutual development of teaching and learning, to achieve a state of coordination and balance between teachers and students, and to realize the co evolution of teachers and students.

\section{Optimization of Classroom Ecological Environment}

\section{Micro Environment Optimization}

The optimization of College English classroom ecology must follow the law of tolerance and the most appropriate principle. The law of tolerance in ecology holds that the tolerance range of organisms to an ecological element is limited, and "too much" or "too little" will have adverse effects. Only when the degree of ecological elements to biological or system is in the most appropriate state, the best development can be achieved for individuals, populations or systems. Therefore, first of all, the relevant management departments of university should provide support and help for the smooth implementation of classroom teaching, and take reasonable measures to solve the problems such as large class teaching brought by the expansion of college students. It is true large class will save teaching resources to some extent, but from the perspective of students' professional development, especially the development of language ability, large class teaching has its disadvantages compare to small lass. The excessive number of class affects the effectiveness of teaching activities and will influence proper development of classroom ecology. Universities can adopt small classes for language teaching, or carry out graded teaching method according to the students' English proficiency and needs, aiming at promoting their language ability. This way also meets the needs of tolerance and adaptability of different educational students' subjects. In this way, universities can focus on not only students' physical and mental growth and development, but also better training on their comprehensive English ability.

Secondly, the ecological factors such as autonomous learning, project-based learning and computer-aided teaching should be reasonably allocated in the classroom ecology, so as to achieve the most appropriate principle. Because only reasonable allocation can make these ecological elements play a positive role and promote the coordination of all elements in classroom ecology. Improper allocation may make them become limiting factors, which will reduce the teaching effect. 


\section{Macro Environment Optimization}

The use of hybrid teaching effectively connects classroom and extra-curricular teaching. The optimization of educational ecology classroom is not only in the university classroom itself, but also outside the classroom, making rational use of internet teaching resources, enhancing teachers' ability to apply information technology teaching and realizing the interaction between teachers and students to change traditional classroom into "Zhi Huiyun classroom" to optimize the macro classroom environment.

With the process of network informatization, the relationship between teachers and students and resources is also undergoing profound changes. For teachers, they are no longer the users of static teaching resources, but the creators of dynamic teaching resources. Outside classroom, according to the actual situation and needs of students, teachers can make online teaching resources or design English learning network platform that students are interested in through class QQ group, Dingding class, public mailbox and class micro-blog home page. They can also design mobile teaching links with the help of mobile learning network resources or application software to guide students to carry out mobile learning according to the teaching schedule, help and guide students to choose mobile learning resources, strengthen the supervision of mobile learning, and give full play to the leading role of teachers. Teachers and students can ask questions, answer questions and discuss with each other anytime and anywhere, so as to realize the flexible, timely, effective and online interactive ubiquitous learning between teachers and students and realize the effective extension of classroom teaching, so as to make the classroom and extracurricular learning ecological balance and harmony.

\section{CONCLUSION}

An ecological approach aims to study the learning process, the actions and activities of teachers and learners, the multilayered nature of interaction and language use, in all their complexity and as a network of interdependence among all the elements in the setting. The sustainable development of ecological classroom requires mutual benefit and symbiosis among all ecological elements to achieve ecological balance. Based on the theory of educational ecology, the author finds that the ecological imbalance in College English listening and speaking classroom is mainly caused by the imbalance of ecological subjects, which leads to the flower pot effect and ecological overload in classroom ecology. In view of these problems, this paper proposes corresponding optimization strategies, in order to eliminate the imbalance and reconstruct a balanced classroom ecology. Only by the collaborative interaction between ecological subjects and various ecological communities in listening and speaking classroom ecosystem can we build a harmonious and balanced and dynamic teaching ecological environment, and achieve the goal of promoting the improvement of students' individual language ability and the overall development.

\section{REFERENCES}

[1] Chen Jianlin. (2010). The Integration of Computer and Networks into Foreign Language Curriculum-A Research Based on College English Reform. Shanghai: Shanghai Foreign Language Education Press.

[2] Chen Jianlin. (2006). On the Integration of Computer and Internet into Foreign Language Teaching Program -From An Ecological Point of View, Computer. Assisted Foreign Language Education, 12, 3-10.

[3] Cheng Xiaotang. (2016). What Should Be Down in the English Classroom? Shandong Foreign Language Teaching, 37(1), 61-67.

[4] Haugen, Einar. (1972). The ecology of language, 325. Stanford: Stanford University Press.

[5] O Malley, J M.\&A.U. Chamot. (1990). Learning Strategies in Second Language Acquisition. Cambridge: Cambridge University Press.

[6] van Lier, L. (2004). The Ecology and Semiotics of Language Learning: A Sociocultural Perspective. Boston: Kluwer Academic Publishers.

Xiaojing Chen was born in Jiangsu, China in 1973. She received her M.Ed. in English Education from Jiangxi Normal University, China in 2007. She is currently an associate professor in School of Foreign Language, Huaiyin Institute of Technology, Jiangsu, China. Her research interests include second language acquisition and college English teaching. 